\title{
Tocopherol and tocotrienol contents in the sea buckthorn berry beverages in Baltic countries: Impact of the cultivar
}

\author{
Paweł Górnaś^ ${ }^{\star}$ Inga Mišina, Inta Krasnova and Dalija Segliņa \\ Institute of Horticulture, Latvia University of Agriculture, Graudu 1, Dobele, LV-3701, Latvia
}

Received 2 May 2015 - Accepted 27 June 2016

\begin{abstract}
Introduction. The soft part of the sea buckthorn (Hippophae rhamnoides L.) berry is not only rich in juice but also in oil, a valuable source of tocopherols and tocotrienols (vitamin E). Therefore, sea buckthorn beverages are becoming increasingly popular in the world market, and may be considered as a valuable source of vitamin E in the daily diet. Materials and methods. The contents of tocopherol and tocotrienol homologues in 28 different commercially available sea buckthorn beverages (nectars and juices) from three Baltic countries, and juice samples obtained in labscale from 6 cultivars of the berries, were studied via RP-HPLC/FLD and a DPPH assay. Results and discussion. A wide range for the total tocochromanol concentration in both commercially available nectars $\left(0.25\right.$ to $\left.26.33 \mathrm{mg} \mathrm{L}^{-1}\right)$ and juices (12.63 to $75.90 \mathrm{mg} \mathrm{L}^{-1}$ ) of sea buckthorn were noted. The profile of tocopherol (T) homologues in the sea buckthorn beverages was as follows: $\alpha$-T (85\%), $\beta$-T $(6.2 \%), \gamma$-T $(2.8 \%)$ and $\delta$-T $(0.6 \%)$. Tocotrienol (T3) homologues constituted only a minor part: $\alpha$-T3 $(1.8 \%), \beta$-T3 $(0.3 \%), \gamma$-T3 $(2.4 \%)$ and $\delta$-T3 $(1.0 \%)$. The total tocochromanol content in the sea buckthorn juice prepared in lab-scale from 6 different cultivars was the lowest for cv. Prozrachnaya and the highest for 'Avgustinka' (39.52 and $73.08 \mathrm{mg} \mathrm{L}^{-1}$, respectively). A significant correlation $(r=0.968, P<0.00001)$ between the total content of tocochromanols in the sea buckthorn beverages and scavenging of free radical DPPH was found. Conclusion. Commercially available sea buckthorn berry beverages had a wide range of the tocochromanol content $\left(0.25-75.90 \mathrm{mg} \mathrm{L}^{-1}\right)$. The juices were found to be the richest source of tocochromanols out of all the beverages studied, mainly in the form of $\alpha$-T (85\%). The concentration of tocochromanols in the sea buckthorn beverages was strongly associated with the antioxidant activity of tested samples determined by the DPPH assay.
\end{abstract}

Keywords: Baltic countries / sea buckthorn / Hipopphae rhamnoides / antioxidant activity / nutritional value / phenolics

Résumé - Teneurs en tocophérol et tocotriénol dans les boissons extraites des baies d'argousier des pays baltes : effet variétal. Introduction. La partie charnue des baies d'argousier (Hippophae rhamnoides L.) est non seulement riche en jus, mais aussi en huile, source précieuse de tocophérols et tocotriénols (vitamine E). Par conséquent, les boissons extraites de l'argousier sont de plus en plus populaire sur le marché mondial, et peuvent être considérées comme une source précieuse de vitamine E dans l'alimentation quotidienne. Matériel et méthodes. Les teneurs en homologues du tocophérol et du tocotriénol d'argousier contenus dans 28 différentes boissons disponibles dans le commerce (nectars et jus) dans trois pays baltes, et celles d'échantillons de jus obtenus à l'échelle du laboratoire à partir des baies de 6 cultivars ont été étudiées par RP -HPLC/FLD et par test au DPPH. Résultats et discussion. Nous avons noté une large gamme de concentrations totales en tocochromanols dans les deux nectars du commerce $\left(0,25\right.$ à 26,33 mg L $\left.\mathrm{L}^{-1}\right)$ et dans les jus d'argousier (12,63 à 75,90 $\left.\mathrm{mg} \mathrm{L}^{-1}\right)$. Les profils en homologues du tocophérol $(\mathrm{T})$ des boissons à base de baies d'argousier ont donné le classement suivant : $\alpha$-T $(85 \%), \beta$-T $(6,2 \%), \gamma$-T $(2,8 \%)$ et $\delta$-T $(0,6 \%)$. Les homologues du tocotrienols (T3) n'ont constitué qu'une partie mineure : $\alpha$-T3 $(1,8 \%), \beta$-T3 $(0,3 \%), \gamma$-T3 $(2,4 \%)$ et $\delta$-T3 $(1,0 \%)$. La teneur totale en tocochromanols dans le jus d'argousier préparé au laboratoire à partir de 6 cultivars différents était la plus basse pour le cv. Prozrachnaya et la plus élevée pour 'Avgustinka' (39,52 et 73,08 mg L ${ }^{-1}$, respectivement). Nous avons trouvé une corrélation significative $(r=0,968, P<0,00001)$ entre la teneur totale en tocochromanols dans les boissons d'argousier et le balayage des radicaux libres DPPH. Conclusion. Les boissons de baies d'argousier disponibles dans le commerce présentent un large éventail de teneurs en tocochromanols $\left(0,25\right.$ à $\left.75,90 \mathrm{mg} \mathrm{L}^{-1}\right)$.

^ Corresponding author: pavel.gornas@lvai.lv 
Les jus de fruits se sont révélés être la source la plus riche en tocochromanols de toutes les boissons étudiées, principalement sous la forme $\alpha$-T (85\%). La concentration de tocochromanols dans les boissons d'argousier est fortement associée à l'activité anti-oxydante des échantillons testés déterminés par test au DPPH.

Mots clés : pays baltes / argousier / Hippophae rhamnoides / activité anti-oxydante / composés phénoliques / valeur nutritionnelle

\section{Introduction}

The sea buckthorn (Hipopphae rhamnoides L.) plant produces valuable yellow-orange berries with 6-9 $\mathrm{mm}$ diameters and is widely grown all over the world. Sea buckthorn berries are a rich source of hydrophilic (organic acids, vitamin $\mathrm{C}$ and phenolic compounds) [1-5] and lipophilic (triacylglycerol, fatty acids, phytosterols, tocochromanols and carotenoids) [1, 6-16] nutritional bio-components. The juice is the main product manufactured from sea buckthorn berries, nevertheless, during juice production, part of the oil (rich in lipophilic compounds, for instance tocochromanols) can be removed from the juice and may be used for other purposes [8].

Tocopherol and tocotrienol homologues (tocochromanols) are bio-compounds with a lipophilic nature and unique physicochemical properties (e.g. important antioxidants in biological systems) [17] and biological activity (vitamin E) [18]. Vita$\min \mathrm{E}$ is essential for the proper physiological functioning of human systems such as neural, vascular, musculoskeletal and reproduction [19]. To date, it is believed that tocotrienols may help to prevent against cancer, diabetes, neurodegenerative and cardiovascular diseases [20]. The Recommended Daily Allowance (RDA) of vitamin $\mathrm{E}$ for adult women and men was originally set at 8 and $10 \mathrm{mg}$ in 1989 respectively. However, the value has been raised for both adult men and women to $15 \mathrm{mg}$ in 2005 [21].

The richest food products with tocochromanols are traditional and unconventional plant oils $[18,22]$ and margarines $[18,23]$. A significantly lower amount of tocopherols in our daily diet is provided by beverages such as coffee [24]. However, some of the beverages obtained from plant material rich in oil yield, especially in the soft parts of fruits, and hence high concentration of tocochromanols, for example sea buckthorn berries [7,10,12], could be considered as a valuable source of vitamin $\mathrm{E}$ in the daily diet.

As the world market of food and beverage products expands daily, the nutritional value on the label is becoming highly important. Therefore, the aim of this study was to investigate the concentration range of tocopherol and tocotrienol homologues in the sea buckthorn berry beverages. Of 28 different products commercially available in Baltic countries, only 4 products have declared concentration of vitamin $\mathrm{E}$ on the label. Additionally, the tocochromanol content was compared with juices prepared in lab-scale from 6 various cultivars of sea buckthorn (Hippophae rhamnoides L.) berries grown in Latvia.

\section{Materials and methods}

\subsection{Reagents}

Four homologues ( $\alpha, \beta, \gamma$ and $\delta$ ) of tocopherol and tocotrienol standards, with a purity of above $95 \%$, were provided by Merck (Darmstadt, Germany) and LGC Standards (Teddington, Middlesex, UK), respectively. Methanol, $n$-hexane, ethanol, ethyl acetate, 2-propanol (HPLC grade), sodium chloride, potassium hydroxide and pyrogallol were obtained from Sigma-Aldrich (Steinheim, Germany).

\subsection{Sea buckthorn beverages}

The 28 sea buckthorn beverages produced by different local manufactures were purchased in April 2013 at the market in Latvia (5 juices and 5 nectars), Lithuania ( 3 juices and 3 nectars) and Estonia (6 juices and 6 nectars). All samples had the shelf life within two months of the labeled expiry date. Only 4 sea buckthorn beverage products have declared the concentration of vitamin $\mathrm{E}$ on their product label.

The sea buckthorn (Hippophae rhamnoides L.) berries of the following cultivars: 'Avgustinka', 'Botanicheskaya Lubitelskaya', 'Prozrachnaya', 'Luchistaya', 'Mary', 'Tatyana' were harvested in Baltplant Ltd., Latvia, using the same method developed in our previous study on sea buckthorn leaves [25]. Early ripened berries of the cv. Botanicheskaya Lubitelskaya were collected in the first week of September; the remaining cultivars in the last week of September 2013. Berries were immediately frozen and stored in refrigerator at $-18{ }^{\circ} \mathrm{C}$ till processing. The thawed berries of sea buckthorn berries $(5.0 \pm 0.5 \mathrm{~kg}$ each $)$ were processed in a R301 Ultra food processor cutter (Robot-Coupe, Vincennes, France) for $3 \mathrm{~min}$, and then the juice was pressed by a Basket press $60 \mathrm{~K}$ (Voran Maschinen, Pichl bei Wels, Austria). The obtained juices were immediately used for the analysis.

\subsection{Extraction of tocochromanols from sea buckthorn beverages}

Sample preparation for tocochromanols determination was performed according to Górnaś et al. [26]. Briefly, $0.5 \mathrm{~mL}$ of the beverage sample was shaken and homogenized for $1 \mathrm{~min}$ using the ultrasonic bath Sonorex RK $510 \mathrm{H}$ (Bandelin Electronic, Berlin, Germany), was placed in a $15 \mathrm{~mL}$ tube with screw cap, and then $2.5 \mathrm{~mL}$ ethanol, $0.05 \mathrm{~g}$ pyrogallol and $0.25 \mathrm{~mL}$ aqueous potassium hydroxide $\left(600 \mathrm{~g} \mathrm{~L}^{-1}\right)$ were added sequentially. The tube was closed immediately and mixed for 


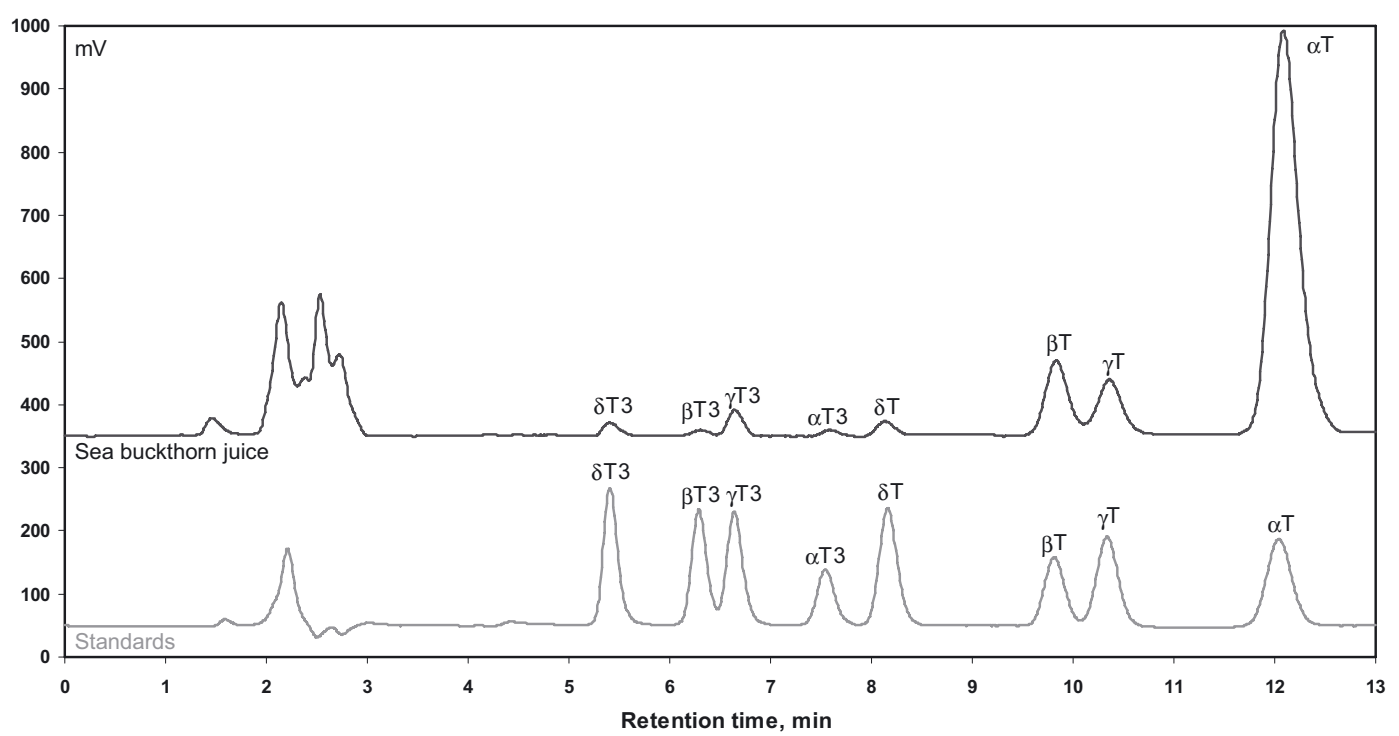

Figure 1. Chromatogram of the tocochromanols separated by RP-HPLC/FLD method in sea buckthorn (Hippophae rhamnoides L.) juice and standards. $\alpha \mathrm{T}, \beta \mathrm{T}, \gamma \mathrm{T}, \delta \mathrm{T}$ and $\alpha \mathrm{T} 3, \beta \mathrm{T} 3, \gamma \mathrm{T} 3, \delta \mathrm{T} 3$ are individual homologues of tocopherols and tocotrienols, respectively.

$10 \mathrm{sec}$, subjected for incubation $(25 \mathrm{~min})$ at $80^{\circ} \mathrm{C}$, and at the 10 min time point of incubation the sample was mixed for 10 sec. After incubation the sample was cooled in an ice-water bath and $2.5 \mathrm{~mL}$ of sodium chloride $\left(10 \mathrm{~g} \mathrm{~L}^{-1}\right)$ was added to reduce the surface tension, and mixed for $5 \mathrm{sec}$. From the saponified sample, tocochromanols were extracted by mixing (15 sec) with $2.5 \mathrm{~mL}$ of $n$-hexane:ethyl acetate $(9: 1$; v/v). After centrifugation $\left(1,000 \times g\right.$, at $\left.4{ }^{\circ} \mathrm{C}, 5 \mathrm{~min}\right)$ the organic layer was transferred to a round bottom flask while residues were re-extracted as described above. The solvents from combined extracts, collected during extraction and re-extractions, were evaporated via a vacuum rotary evaporator till dry and dissolved in 2-propanol ( $2 \mathrm{~mL})$, filtrated through a syringe filter $(0.22 \mu \mathrm{m})$ to a vial, and finally injected directly into the RPHPLC system.

\subsection{Characterization of tocopherols and tocotrienols via RP-HPLC/FLD}

Tocochromanols were quantified according to Górnaś et al. [27]. The HPLC analyses were performed on the Shimadzu system (Shimadzu, Kyoto, Japan) using a fluorescence detector (RF-10AXL) set on $295 \mathrm{~nm}$ (excitation) and $330 \mathrm{~nm}$ (emission). Tocopherol and tocotrienol homologues were separated on the Luna PFP column $(3 \mu \mathrm{m}, 150 \times 4.6 \mathrm{~mm})$ (Phenomenex, Torrance, CA, USA) protected by a guard column $(4 \times 3 \mathrm{~mm})$, using methanol:water $(93: 7 ; \mathrm{v} / \mathrm{v})$ as the mobile phase set at a flow rate of $1.0 \mathrm{~mL} \mathrm{~min}^{-1}$. The column oven had a nominal temperature $40^{\circ} \mathrm{C}$, while the room temperature was thermostated at, $22 \pm 1{ }^{\circ} \mathrm{C}$. The total separation time was 13 min.

\subsection{DPPH assay}

The DPPH assay was carried out according to Górnaś [28]. Briefly, $0.005 \mathrm{~g}$ of DPPH radicals was weighed into a $250 \mathrm{~mL}$ flask and supplemented with $96 \%$ (v/v) ethanol $(250 \mathrm{~mL})$, then, ultrasonicated in a Sonorex RK $510 \mathrm{H}$ (Bandelin electronic, Berlin, Germany) for $0.5 \mathrm{~min}$ to completely dissolve the DPPH radicals. The resulting absorption value was 0.670 \pm 0.01 , at $\lambda_{\max }$ of $517 \mathrm{~nm}$ measured via a spectrophotometer 1650 PC (Shimadzu Corporation, Kyoto, Japan). After saponification, $0.2 \mathrm{~mL}$ of the tested samples and $3.8 \mathrm{~mL}$ of the DPPH solution were mixed, and after $30 \mathrm{~min}$ storage in the dark, the absorbance was measured at a wavelength of $517 \mathrm{~nm}$. The antioxidant activity for each sample was calculated according to the equation below:

$$
\begin{aligned}
& \% \text { DPPH scavenging } \\
= & {\left[\frac{\text { Absorbance of control }- \text { Absorbance of sample }}{\text { Absorbance of control }}\right] \times 100 }
\end{aligned}
$$

\subsection{Statistical analysis}

The results were presented as means \pm standard deviation $(n=3)$. The $P$-value $<0.05$ was applied to denote significant differences between mean values determined by one-way analysis of variance (ANOVA) and the Bonferroni post-hoc test via the software Statistica 10.0 (StatSoft, Tulsa, OK, USA).

\section{Results and discussion}

All homologues of tocopherols and tocotrienols (figure 1) were detected in $90 \%$ of the studied sea buckthorn samples that were commercially available and obtained in lab-scale. Similar tocochromanol composition was previously reported in the oil fraction recovered from sea buckthorn berries [12]. The $\alpha$ $\mathrm{T}$ was a predominant form reaching an average of $85 \%$ of the total tocochromanol content in the sea buckthorn berry beverages. The $\beta$-T, $\gamma$-T and $\delta$-T constituted an average of 6.2 , 
2.8 and $0.6 \%$, respectively. In case of tocotrienols, the $\alpha$-T3 and $\gamma$-T3 constituted an average 1.8 and $2.4 \%$, respectively. The remaining part $(1.3 \%)$ constituted $\beta$-T3 and $\delta$-T3. High abundance of $\alpha$-T is characteristic of the soft parts (pulp and peel) of sea buckthorn berries [10], their seeds [10,29] and leaves [25]. The higher level of $\beta$-T compared to $\gamma$-T, is an unusual phenomenon in the plant world, especially in fruit seeds, since in most of plants the lack or very low amount of $\beta$-T is often reported $[25,30]$. Exceptions have been reported in coffee beans [31] and apple seeds [26] where the $\beta$-T was dominant over the $\gamma$-T.

The concentration of the individual tocopherol and tocotrienol homologues in the commercial sea buckthorn beverages from all three Baltic countries (Lithuania, Latvia and Estonia, showed a large variation which are clearly illustrated by the range of the total amount of tocochromanols from 0.25 to $75.90 \mathrm{mg} \mathrm{L}^{-1}$ (table I). The mean and range concentration of each individual tocopherol and tocotrienol homologues in the sea buckthorn beverages (listed for each country) were not dependent on the market of product origin. The wide range of tocochromanol concentration could be associated with the different concentration of sea buckthorn juice in the studied beverages. Therefore, the samples were separated into two groups, juice and nectars, in line with the manufacturers' description. Two important outcomes should be highlighted. Firstly, the total content of tocochromanols was on average over five times higher for the juices in comparison to the nectars. Secondly, for each tocopherol and tocotrienol homologue in the nectars the standard deviation had an approximately similar value as the mean concentration of the individual tocochromanol. This observation showed a high variation in the content of individual tocochromanols in sea buckthorn nectars. In the group of juice samples the standard deviation constituted about half of the mean concentration value of individual tocopherol and tocotrienol homologues (table I). According to CODEX STAN 247, nectars must contain at least $25 \%(\mathrm{v} / \mathrm{v})$ of sea buckthorn juice or fruit puree [32]. Based on the recorded concentration of tocochromanols these minimum requirements were not met in some of the studied nectar products. However, since the concentration of tocochromanols is dependent on the time of harvesting $[7,10,12]$ and more importantly on the subspecies and cultivar of sea buckthorn berries $[7,10]$ the six most popular grown cultivars in Baltic countries were studied. The significant differences $(P<0.05)$ were obtained between individual and total tocochromanols levels in the obtained juice of six sea buckthorn berries cultivars (table II). The lowest concentration of total identified tocochromanols was recorded for the cv. Prozrachnaya and the highest for 'Avgustinka' (39.52 and $73.08 \mathrm{mg} \mathrm{L}^{-1}$, respectively). These values are within the total tocochromanol concentration range of the commercially available juices (12.63$75.90 \mathrm{mg} \mathrm{L}^{-1}$ ). The average and the mean levels of total tocochromanols, for six tested cultivars, were $49.86 \pm 12.50$ and $39.52-73.08 \mathrm{mg} \mathrm{L}^{-1}$ respectively, whereas for commercial juices $46.24 \pm 20.00$ and $12.63-75.90 \mathrm{mg} \mathrm{L}^{-1}$ respectively. The average and the highest concentrations in both cases of the studied samples were very similar, however, the standard deviation is almost twice higher and the minimum level of total tocochromanols is three-fold lower for the commercial juices 
compared to the obtained juices prepared in lab-scale. This indicated that the lower content of tocopherols and tocotrienols in some commercially available sea buckthorn juices may be the result of the addition of cheaper substitutes, different varieties or species, as well as the possibility that a part of the lipid fraction was removed from the obtained juices. The storage time and conditions of the beverages may also have an impact on the vitamin E content, however, the $\alpha$-T which represented $85 \%$ of total tocochromanols in sea buckthorn beverages has been shown to be relatively stable even during the conventional drying of sea buckthorn leaves [25].

To the best of our knowledge this is the first report of the tocopherol and tocotrienol concentrations in sea buckthorn berry beverages. In previous studies tocochromanols were determined in the soft parts (pulp and peel) [10] or in oil recovered from the fruit fraction [12] and therefore, direct comparison is not possible.

Tocochromanols have been reported as strong lipophilic antioxidants in different model systems [17,33]. In order to determine and compare the antioxidant activity of studied sea buckthorn beverages a well-established and reliable DPPH assay was applied. The capacity in scavenging of free radicals by DPPH was associated with the concentration of tocochromanols. Consequently, the lowest antioxidant activity was noted for the sample with the lowest content of tocochromanols and the highest for the sample with the highest levels. Furthermore, a significant correlation resulted $(r=0.968$, $P<0.00001)$ between the total content of tocochromanols in the sea buckthorn beverages and scavenging of free radical DPPH (figure 2). This observation may indicate that tocopherols and tocotrienols are the main lipophilic antioxidants of sea buckthorn berry beverages which interact with the DPPH radicals. A similar observation was reported in plant oils [22]. As sea buckthorn products are very rich in carotenoids, additional tests with the $\alpha$-T and $\beta$-carotene standards confirmed that high $\beta$-carotene concentrations reacted only at minor levels with the DPPH radicals (data not shown).

\section{Conclusion}

The commercially available sea buckthorn berry beverages had a wide range of the tocochromanol content $(0.25-$ $75.90 \mathrm{mg} \mathrm{L}^{-1}$ ). The findings of this study highlighted that only part of the sea buckthorn berry beverages, the juices, can be considered as a rich source of tocochromanols, mainly in the form of $\alpha$-T (85\%). The results of the DPPH assay showed a strong association between the concentrations of tocochromanols in the sea buckthorn beverages with the antioxidant activities of the tested samples. From a nutritional point of view the inclusion of the tocochromanol content on the label of the sea buckthorn beverages should be included to facilitate an improved consumers' control on their vitamin E daily dietary intake. 


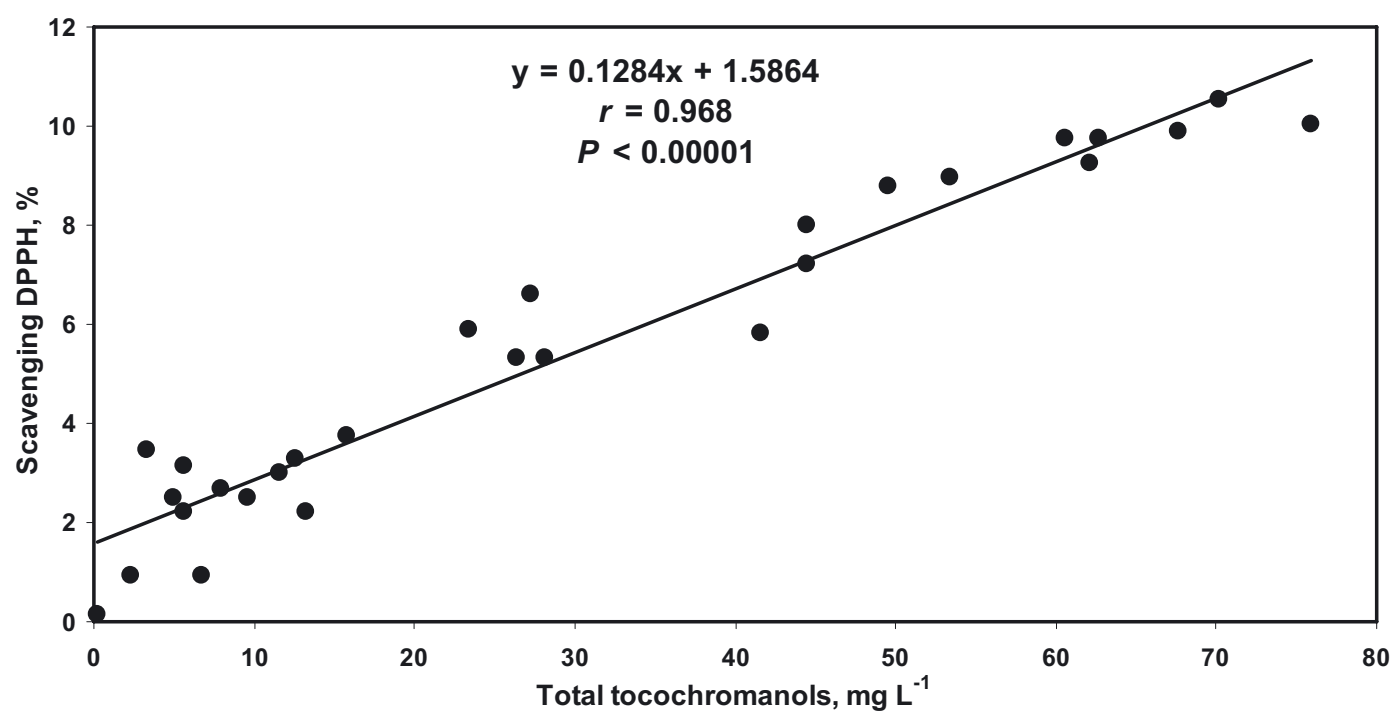

Figure 2. Correlation between the total tocochromanol content $\left(\mathrm{mg} \mathrm{L}^{-1}\right)$ and the DPPH radical-scavenging activity (\%) of sea buckthorn beverages' saponified fractions.

\section{References}

[1] Raffo A., Paoletti F., Antonelli M., Changes in sugar, organic acid, flavonol and carotenoid composition during ripening of berries of three seabuckthorn (Hippophae rhamnoides L.) cultivars, Eur. Food Res. Technol. 219 (2004) 360-368.

[2] Tiitinen K.M., et al., Fast analysis of sugars, fruit acids, and vitamin $\mathrm{C}$ in sea buckthorn (Hippophae rhamnoides $\mathrm{L}$.) varieties. J. Agric. Food Chem. 54 (2006) 2508-2513.

[3] Ma X., et al., Flavonol glycosides in berries of two major subspecies of sea buckthorn (Hippophaë rhamnoides L.) and influence of growth sites. Food Chem. 200 (2016) 189-198.

[4] Yang W., et al., Proanthocyanidins in Sea Buckthorn (Hippophaë rhamnoides L.) Berries of Different Origins with Special Reference to Influence of Genetic Background and Growth Location, J. Agric. Food Chem. 64 (2016) 1274-1282.

[5] Zheng J., Kallio H., Yang B., Sea buckthorn (Hippophä̈ rhamnoides ssp. rhamnoides) berries in Nordic environment: Compositional response to latitude and weather conditions, J. Agric. Food Chem, (2016), DOI: 10.1021/acs.jafc.1026b00682.

[6] Andersson S.C., et al., Carotenoids in sea buckthorn (Hippophae rhamnoides L.) berries during ripening and use of pheophytin a as a maturity marker, J. Agric. Food Chem. 57 (2009) 250-258.

[7] Andersson S.C., et al., Tocopherols and tocotrienols in sea buckthorn (Hippophae rhamnoides L.) berries during ripening, J. Agric. Food Chem. 56 (2008) 6701-6706.

[8] Beveridge T., et al., Sea buckthorn products: manufacture and composition, J. Agric. Food Chem. 47 (1999) 3480-3488.

[9] Giuffrida D., et al., Determination of carotenoids and their esters in fruits of sea buckthorn (Hippophae rhamnoides L.) by HPLCDAD-APCI-MS, Phytochem. Anal. 23 (2012) 267-273.

[10] Kallio H., Yang B., Peippo P., Effects of different origins and harvesting time on vitamin $\mathrm{C}$, tocopherols, and tocotrienols in sea buckthorn (Hippophä̈ rhamnoides) berries, J. Agric. Food Chem. 50 (2002) 6136-6142.

[11] Pop R.M., et al., Carotenoid composition of berries and leaves from six Romanian sea buckthorn (Hippophae rhamnoides L.) varieties, Food Chem. 147 (2014) 1-9.
[12] St. George S.D., Cenkowski S., Influence of harvest time on the quality of oil-based compounds in sea buckthorn (Hippophae rhamnoides L. ssp. sinensis) seed and fruit, J. Agric. Food Chem. 55 (2007) 8054-8061.

[13] Yang B., Kallio H., Composition and physiological effects of sea buckthorn (Hippophae) lipids, Trends Food Sci. Technol. 13 (2002) 160-167.

[14] Yang B., et al., Phytosterols in sea buckthorn (Hippophae rhamnoides L.) berries: identification and effects of different origins and harvesting times, J. Agric. Food Chem. 49 (2001) 5620 5629.

[15] Vuorinen A.L., et al., Effect of growth environment on the gene expression and lipids related to triacylglycerol biosynthesis in sea buckthorn (Hippophä rhamnoides) berries, Food Res. Int. 77 (2015) 608-619.

[16] Teleszko M., et al., Analysis of lipophilic and hydrophilic bioactive compounds content in sea buckthorn (Hippophae rhamnoides L.) berries, J. Agric. Food Chem. 63 (2015) 4120-4129.

[17] Nogala-Kałucka M., et al., Antioxidant synergism and antagonism between tocotrienols, quercetin and rutin in model system, Acta Aliment. 42 (2013) 360-370.

[18] Eitenmiller R., Lee J., Vitamin E: food chemistry, composition, and analysis. Marcel Dekker Inc., New York, 2004.

[19] Burton G.W., Vitamin E: molecular and biological function, Proc. Nutr. Soc. 53 (1994) 251-262.

[20] Aggarwal B.B., et al., Tocotrienols, the vitamin E of the 21st century: its potential against cancer and other chronic diseases, Biochem. Pharmacol. 80 (2010) 1613-1631.

[21] DellaPenna D., A decade of progress in understanding vitamin E synthesis in plants, J. Plant Physiol. 162 (2005) 729-737.

[22] Górnaś P., Soliven A., Segliòa D., Seed oils recovered from industrial fruit by-products are a rich source of tocopherols and tocotrienols: Rapid separation of $\alpha / \beta / \gamma / \delta$ homologues by RPHPLC/FLD, Eur. J. Lipid Sci. Technol. 117 (2015) 773-777.

[23] Górnaś P., Siger A., Simplified sample preparation and rapid detection by RP-HPLC/FLD of tocopherols and tocotrienols in margarines: Preliminary screening of plant fats - potential quality markers, Eur. J. Lipid Sci. Technol. 117 (2015) 1589-1597. 
[24] Górnaś P., et al., Factors affecting tocopherol contents in coffee brews: NP-HPLC/FLD, RP-UPLC-ESI/MS ${ }^{\mathrm{n}}$ and spectroscopic study, Eur. Food Res. Technol. 238 (2014) 259-264.

[25] Górnaś P., et al., Sea buckthorn (Hippophae rhamnoides L.) leaves as valuable source of lipophilic antioxidants: The effect of harvest time, sex, drying and extraction methods, Ind. Crops Prod. 60 (2014) 1-7.

[26] Górnaś P., et al., Dessert and crab apple seeds as a promising and rich source of all four homologues of tocopherol $(\alpha, \beta, \gamma$ and $\delta$ ), LWT-Food Sci. Technol. 59 (2014) 211-214.

[27] Górnaś P., et al., An alternative RP-HPLC method for the separation and determination of tocopherol and tocotrienol homologues as butter authenticity markers: A comparative study between two European countries, Eur. J. Lipid Sci. Technol. 116 (2014) 895-903.

[28] Górnaś P., Unique variability of tocopherol composition in various seed oils recovered from by-products of apple industry: Rapid and simple determination of all four homologues $(\alpha, \beta$, $\gamma$ and $\delta$ ) by RP-HPLC/FLD, Food Chem. 172 (2015) 129-134.
[29] Górnaś P., Pugajeva I., Segliòa D., Seeds recovered from byproducts of selected fruit processing as a rich source of tocochromanols: RP-HPLC/FLD and RP-UPLC-ESI/MS ${ }^{\mathrm{n}}$ study, Eur. Food Res. Technol. 239 (2014) 519-524.

[30] Górnaś P., et al., Tocochromanols composition in kernels recovered from different apricot varieties: RP-HPLC/FLD and RPUPLC-ESI/MS ${ }^{\mathrm{n}}$ study, Nat. Prod. Res. 29 (2015) 1222-1227.

[31] Górnaś P., et al., New insights regarding tocopherols in Arabica and Robusta species coffee beans: RP-UPLC-ESI/MS ${ }^{\mathrm{n}}$ and NPHPLC/FLD study, J. Food Compos. Anal. 36 (2014) 117-123.

[32] CODEX_STAN_247, General standard for fruit juices and nectars, http://www.codexalimentarius.org. (2005).

[33] Dwiecki K., et al., Spectroscopic studies of D- $\alpha$-tocopherol concentration-induced transformation in egg phosphatidylcholne vesicles, Cell. Mol. Biol. Lett. 12 (2007) 51-69. 